\title{
ON THE RELATION OF THE SPECIFIC GRAVITY OF URINE TO THE SOLIDS PRESENT.
}

BY J. H. I,ONG.
Received December $29,1902$.

ATTEMPTs have been made several times to establish a relation between the specific gravity of normal urine and the weight of solids dissolved in the secretion. Such efforts are naturally based on the assumption that while the solids must vary, the variations remain within rather narrow limits and the two most important constituents must change in the same direction. These two important substances are urea and sodium chloride, and the specific gravity observed depends largely on the weight of these bodies present.

From early experiments of Trapp, Haeser and others, repeated later by Neubauer, ${ }^{1}$ the relation appeared in general to be definite enough to warrant the use of the so-called coefficient of Haeser in making an approximate estimation of the urine solids from an exact determination of the specific gravity. The direct estimation of solids by evaporation is apparently easy, but unfortunately is liable to an error due to the partial decomposition of urea into ammonium cyanate and that into ammonia and carbonic acid. In addition to this, there is a loss on account of the slightly stable ammonium salts present, which fact is generally overlooked, although its importance is as great as that of the loss from the urea, in some cases. Unless a correction is made for these losses, the error in the final result is rather large, in fact usually larger than is the difference between the true result and that obtained by applying the coefficient of Haeser.

As this is a point of no little importance, I have recently undertaken a new determination of the urinary solids along with the corresponding specific gravities, both determinations being made as accurately as possible. The solid residue was found by the method originally suggested by Neubauer. About 5 grams of urine are evaporated in a porcelain boat which is placed in a horizontal glass tube passing through a steam-bath. The glass tube is connected with a small flask containing standard sulphuric acid in such a manner that a current of dried air may be aspirated through the whole apparatus and carry evolved products into the

1 Ztschr. anal. Chem.. 1, 166. 
standard acid. A stubsequent titration with standard alkali and methyl orange shows how much acid has been neutralized by ammonia from the evaporated urine. Three to four hours are given to each evaporation, after which the residue in the boat is allowed to stand about two hours over sulphuric acid before weighing. Neubauer suggested to calculate the ammonia absorbed by the dilute standard acid to urea and add this to the weight of the residue. This has been done in the urine evaporations given below, although the method is not strictly correct. as will be pointed out.

The specific gravities were found by means of a small pycnometer and at a temperature maintained at $25^{\circ}$, with a variation within $0.1^{\circ}$. For possible practical applications, $25^{\circ}$ is a much more suitable temperature than is $15^{\circ}$ or even $20^{\circ}$. The results are referred to water at $4^{\circ}$ as unity and are all given below.

Some preliminary experiments were made to determine the loss in evaporating solutions containing pure urea and certain salts in proportions corresponding to those obtaining for urine. In the first of these I took, with water enough to make about $+\mathrm{cc}$. :

\begin{tabular}{|c|c|c|}
\hline $\mathrm{NaCl} \ldots \ldots \ldots \ldots \ldots \ldots \ldots \ldots \ldots$ & $\begin{array}{c}(a) \\
0.0930\end{array}$ & $\begin{array}{c}(h) \\
0.0708\end{array}$ \\
\hline \multirow{3}{*}{$\begin{array}{l}\mathrm{K}_{2} \mathrm{SO}_{4} \ldots \ldots \ldots \ldots \ldots \ldots \ldots \ldots \ldots \ldots \ldots \ldots \ldots \ldots \ldots \ldots \\
\mathrm{CON}_{2} \mathrm{H}_{4} \ldots \ldots \ldots \ldots \ldots \ldots \ldots \ldots\end{array}$} & 0.0077 & 0.0059 \\
\hline & o. 1467 & O.III \\
\hline & 0.2474 & O. I 884 \\
\hline \multirow{3}{*}{$\begin{array}{l}\text { Residue recovered } \ldots \ldots \ldots \ldots \ldots \ldots \ldots \\
\text { Urea from ammonia } \ldots \ldots \ldots \ldots \ldots \ldots\end{array}$} & $0.243^{\circ}$ & $0.185 \mathrm{I}$ \\
\hline & 0.0052 & 0.0037 \\
\hline & 0.2482 & 0.188 \\
\hline
\end{tabular}

In the first case, the loss of $5.2 \mathrm{mg}$. of urea calculated from the ammonia is 3.5 per cent. of the urea present or 2 .I per cent. of the solids. In the second case, $3.7 \mathrm{mg}$. amounts to 3.3 per cent. of the whole urea, or 2 per cent. of the total solids. Very similar results were found in other tests and need not be given in detail. In the following experiments the effect of a phosphate was determined. With water enough to make about $3.5 \mathrm{cc}$. in each case, I took:

\begin{tabular}{|c|c|c|}
\hline $\mathrm{NaCl}, \ldots \ldots \ldots \ldots \ldots \ldots \ldots \ldots$ & $\begin{array}{c}(c) . \\
\text { O.IT26 }\end{array}$ & $\begin{array}{c}(d) \\
0.088 \mathrm{I}\end{array}$ \\
\hline $\mathrm{K}_{2} \mathrm{SO}_{4} \ldots \ldots \ldots \ldots \ldots \ldots \ldots \ldots \ldots$ & 0.0080 & 0.0101 \\
\hline $\mathrm{HNa}_{2} \mathrm{PO}_{4} \ldots \ldots \ldots \ldots \ldots \ldots \ldots$ & 0.0120 & 0.0120 \\
\hline $\mathrm{CON}_{2} \mathrm{H}_{4} \ldots \ldots \ldots \ldots \ldots \ldots \ldots \ldots$ & 0.1526 & 0.1927 \\
\hline & 0,2 & \\
\hline
\end{tabular}


The evaporation was continued three and a half hours, and the ammonia was caught as before.

$\begin{array}{lll}\text { Recovered directly } \ldots \ldots \ldots \ldots \ldots \ldots & \frac{0.2830}{0.0022} & \frac{0.299 \mathrm{I}}{0.0038}\end{array}$

The ammonia evolved was found in $(c)$ to be equal to $0.5 \mathrm{cc}$. of $\mathrm{N} / 4$ acid and in $(d)$ to $0.6 \mathrm{cc}$. of N/4 acid. Calculating this as urea would more than account for the loss. In this case, however, a part of the carbonic acid from the urea decomposition is held by the alkali phosphate. In (c) the total loss was $14.4 \mathrm{mg}$. per gram of urea, or I.44 per cent. of the total urea. In $(d)$ the loss was $19.2 \mathrm{mg}$. per gram of urea or 1.92 per cent. of the urea present. These losses are about one-half as great as they were in the absence of the alkali phosphate.

Since the urine is commonly slightly acid and probably from the presence of the dihydrogen phosphate, two further evaporations were made with known amounts of this salt present. It was produced by addition of $\mathrm{N} /$ Io sulphuric acid to a solution of the disodium salt. The weights taken, with water enough to make up $4.5 \mathrm{cc}$, were :

\begin{tabular}{|c|c|c|}
\hline & $(e)$ & $\begin{array}{ll}(f) . \\
0.1053\end{array}$ \\
\hline 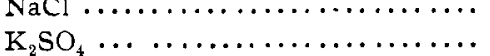 & $\begin{array}{l}0.1046 \\
0.0099\end{array}$ & $\begin{array}{l}0.1053 \\
0.0100\end{array}$ \\
\hline $\mathrm{Na}_{2} \mathrm{SO}_{4}, \ldots \ldots \ldots \ldots \ldots \ldots \ldots \ldots$ & 0.0060 & 0.0060 \\
\hline $\mathrm{H}_{2} \mathrm{NaPO}_{4} \ldots \ldots \ldots \ldots \ldots \ldots \ldots \ldots$ & 0.0100 & 0.0100 \\
\hline \multirow{2}{*}{$\mathrm{CON}_{2} \mathrm{H}_{4} \ldots \ldots \ldots \ldots \ldots \ldots \ldots \ldots$} & 0.1893 & 0.1900 \\
\hline & 0.3198 & 0.3213 \\
\hline Recovered directly $\ldots \ldots \ldots \ldots \ldots$ & 0.3171 & 0.3174 \\
\hline $\begin{array}{l}\text { Loss } \ldots \ldots \ldots \ldots \ldots \ldots \ldots \ldots \ldots \ldots \\
\text { The ammonia evolved calculated as }\end{array}$ & 0.0028 & \\
\hline urea gives ...................... & 0.0023 & 0.0037 \\
\hline
\end{tabular}

In such cases, therefore, it seems perfectly proper to add urea to correct the evaporation loss, and the presence of the salts does not appear to increase this appreciably. The decomposition with alkaline phosphate present is probably the same, but the ammonia only is fully liberated.

Below are given the results of fifty-two determinations on the urine of six persons. The samples taken for the tests did not represent the excretion of the whole day but were chosen to represent extreme cases, as far as possible, as the main object of the 
investigation was to determine the limits of variations. From other investigations, the average amounts of urea and ammonia excreted by the same individuals, under the same general conditions, had been determined. The urea amounted to 28 grams per liter and the ammonia to $650 \mathrm{mg}$. per liter. All the tests were made on perfectly fresh urine, from individuals in normal health, consuming an average meat, vegetable and bread diet.

\begin{tabular}{|c|c|c|c|c|}
\hline No. & Sp. gr. ${ }_{4}^{2}$ & $\begin{array}{l}\text { Solids } \\
\text { in grams } \\
\text { per liter. }\end{array}$ & $\begin{array}{c}\text { Loss as } \\
\text { urea, grams } \\
\text { per liter. }\end{array}$ & $\begin{array}{l}\text { Multiplication } \\
\text { factor. }\end{array}$ \\
\hline I & I.0199 & $5 \mathrm{I} \cdot 57$ & 2.36 & 0.259 \\
\hline 2 & 1.0207 & 51.19 & 2.95 & 0.247 \\
\hline 3 & 1.0206 & 52.33 & 2.37 & 0.254 \\
\hline 4 & 1.0189 & 44.28 & $2.2 \mathrm{~S}$ & 0.234 \\
\hline 5 & 1.0209 & 53.70 & 2.54 & 0.257 \\
\hline 6 & 1.0215 & 53.10 & 1.72 & 0.247 \\
\hline 7 & 1.0227 & 61.93 & 2.89 & 0.272 \\
\hline 8 & 1.0217 & 53.55 & 2.46 & 0.247 \\
\hline 9 & 1.0224 & 56.54 & $2 . I_{3}$ & 0.252 \\
\hline 10 & 1.0180 & 53.84 & 2.51 & 0.299 \\
\hline II & 1.0252 & 66.05 & 2.56 & 0.262 \\
\hline I 2 & $\mathrm{I} .025 \mathrm{I}$ & 63.54 & 2.10 & 0.253 \\
\hline I3 & 1.0226 & 57.19 & I. $7 \mathrm{I}$ & 0.253 \\
\hline 14 & $I .0231$ & 60.00 & 1.95 & 0.260 \\
\hline I5 & 1.0236 & $57 \cdot 38$ & 1.76 & 0.243 \\
\hline 16 & 1.0236 & 62.82 & 2.35 & 0.266 \\
\hline I 7 & I. .0248 & 59.90 & 2.74 & 0.242 \\
\hline I8 & 1.0279 & 70.73 & I. 75 & 0.254 \\
\hline I9 & 1.0230 & 59.31 & 1.70 & 0.258 \\
\hline 20 & 1.0279 & $75.2 \mathrm{r}$ & I. 96 & 0.270 \\
\hline $2 \mathrm{I}$ & 1.0223 & $57.4 \mathrm{~S}$ & 2.09 & $0.25^{8}$ \\
\hline 22 & 1.0177 & $43 \cdot 13$ & I. 60 & 0.244 \\
\hline 23 & $\mathrm{I} .023 \mathrm{I}$ & 63.06 & 1.92 & 0.273 \\
\hline 24 & 1.0228 & 58.37 & 2.15 & 0.256 \\
\hline 25 & $1.028_{4}$ & 75.55 & 1.67 & 0.266 \\
\hline 26 & 1.0256 & 73.26 & 2.34 & 0.288 \\
\hline 27 & 1.0246 & 59.75 & 1.93 & 0.243 \\
\hline 28 & I.OIgI & $44.9^{8}$ & 2.00 & 0.235 \\
\hline 29 & $\mathrm{I} .03 \mathrm{I} 7$ & 79.29 & 2.31 & 0.250 \\
\hline 30 & I.OII8 & 30.02 & 0.97 & 0.254 \\
\hline $3 \mathrm{I}$ & 1.0237 & 63.45 & 4.53 & 0.268 \\
\hline 32 & 1.0207 & 51.06 & 1.73 & 0.247 \\
\hline 33 & I. $.029 \mathrm{I}$ & 70.90 & 4.19 & 0.244 \\
\hline 34 & 1.0243 & $62.4 I$ & $2.8 \mathrm{I}$ & 0.257 \\
\hline 35 & 1.0140 & 37.81 & $2.0 \mathrm{I}$ & $0.27^{\circ}$ \\
\hline 36 & 1.0217 & $5^{6.5} 6$ & 2.40 & $0.26 \mathrm{I}$ \\
\hline 37 & 1.0225 & 59.29 & 2.75 & 0.264 \\
\hline
\end{tabular}




\begin{tabular}{|c|c|c|c|c|}
\hline No. & Sp. gr. ${ }^{25^{\circ}} 4$ & $\begin{array}{l}\text { Solids } \\
\text { in grams } \\
\text { per liter. }\end{array}$ & $\begin{array}{l}\text { Loss as } \\
\text { urea, grams } \\
\text { per liter. }\end{array}$ & $\begin{array}{l}\text { Multiplication } \\
\text { factor. }\end{array}$ \\
\hline $3^{8}$ & 1.0165 & $45 \cdot 13$ & 2.49 & 0.274 \\
\hline 39 & 1.0212 & 60.01 & 3.64 & 0.283 \\
\hline 40 & 1.0155 & 43.08 & 2.91 & 0.278 \\
\hline $4 I$ & 1.0247 & 62.74 & 1.62 & 0.254 \\
\hline 42 & 1.0113 & 33.47 & 2.26 & 0.296 \\
\hline 43 & $1.016 \mathrm{I}$ & 44.72 & 2.03 & 0.277 \\
\hline 44 & $\mathrm{I} .020 \mathrm{I}$ & 53.46 & I.6I & 0.266 \\
\hline 45 & $\mathrm{I} .023 \mathrm{I}$ & 60.95 & 2.38 & 0.264 \\
\hline 46 & 1.0225 & 55.47 & 0.98 & 0.242 \\
\hline 47 & 1.0221 & 56.19 & 1.83 & 0.254 \\
\hline 48 & 1.0120 & 31.69 & 1.56 & 0.264 \\
\hline 49 & 1.0160 & $4 I .84$ & 1.60 & $0.26 \mathrm{I}$ \\
\hline 50 & I.0215 & 53.98 & I. 70 & $0.25 \mathrm{I}$ \\
\hline 5 I & 1.0267 & $68.9 \mathrm{I}$ & 1.17 & $0.25^{8}$ \\
\hline 52 & 1.0160 & 41.26 & 2.12 & $0.25^{8}$ \\
\hline & 1.0215 & $55.8_{3}$ & 2.19 & 0.260 \\
\hline
\end{tabular}

The evaporation losses calculated as urea, from the ammonia evolved, are seen to be far greater with the urine than with the artificial mixtures. With an average of 28 grams of urea in the urine the mean loss is evidently about 8 per cent. of this content. While as a matter of convenience it is satisfactory to calculate the loss as urea, a little consideration will show that a part of it must come from other sources. In the evaporation, part of the ammonia present, and possibly sometimes all of it, is driven off and this may be considered as combined as some organic salt and possibly partly as carbonate. In one case the loss would be less and in the other greater than that found by calculation as urea. The usual method of calculation probably represents the average loss, and this has been included in the figures representing the total solids in column 3 .

The correspondence between high specific gravity and high solids is a fairly good one in most cases, as shown by the factor in the last column, representing the so-called Haeser coefficient for the temperature of $25^{\circ}$. This factor is obtained by dividing the last three figures of the specific gravity into the weight of solids found. In most cases the variations are not great from the mean value of 0.260 , but in Nos. 4 , IO, 26, 28 , and 42 the divergence is much greater than given by Neubauer. For the mixed day's urine the results would be much closer and in any such case the factor 0.260 would not be far from the truth. This factor can be 
applied only when the specific gravity is taken at $25^{\circ}$, for which temperature many urinometers are now adjusted. For an instrument graduated to give the specific gravity at $20^{\circ}$ referred to water at $4^{\circ}$ the factor to be used is 0.234 . This was found by making a number of cleterminations of the specific gravity at the two temperatures and calculating the average coefficient of expansion. Neubauer's average factor is 0.233 , based on urine at $I 5^{\circ}$ referred to water at $0^{\circ}$. For the same temperature limits the results are practically identical, which indicates that for normal mixed urine the coefficient has a sharp definite value, and that it may be used as a control in certain kinds of analyses. Results of still greater value in practice may doubtless be secured through the exact determination of a factor for the solids, cxclusive of the sodium chloride, that is, for the products of metabolic origin. A series of determinations in this direction is now in progress.

In any case the exact determination of the total solids by evaporation does not appear to be possible because of the uncertainty as to how the ammonia loss should be calculated.

My thanks are due to Mr. C. MV. Brown, who made many of the determinations given above.

NORTHWESTERI UNIVERSITY,

Chrcago, December, igor.

[CONTRIBUTIONS FROM THF CHEMICAL IAAORATORY OF THE PENNSYT.VANIA STATE COLLEGE.]

\section{DERIVATIVES OF ISOSAFROL AND ISOAPIOL.}

BY F. J. POND ANDC. R. SIEGFRIEI.

Received January 2, Jģڤ.

In a previous paper, ${ }^{1}$ certain compounds were described which were found to result by the action of hot methyl and ethyl alcohols upon the bromine derivatives of anethol, isosafrol, ethyl isoeugenol and isoapiol; it was stated that these compounds are formed by the replacement of the bromine atom in the side-chain, which stands in the $\alpha$-position to the benzene ring, by the methoxyland ethoxyl-groups. Thus, for example, a compound having the formula,

1 Pond, Erb and Ford: This Journa!, 24, 327. 